\title{
An assessment of composition and diversity of fin fish in the upper course of Otamiri river, Imo State, South-Eastern Nigeria
}

\begin{abstract}
The composition and diversity of the fin fish of upper course of Otamiri River was study for the period of three months to evaluate the likely effects of the recent anthropogenic activities around the river on the fish species. Water sample for physcio-chemical parameter were collected and analyses using conventional field and standard laboratory techniques. Likewise, the fish samples were collected bi-weekly using active and passive fishing gear. All the physic-chemical parameters measured fall within the standard recommended limit for aquatic management except the $\mathrm{pH}$, ammonia, total suspended solid, Nitrate and carbon (iv) oxides. Also, sixteen species of fish belong to 9 fish families were recorded with the families, Cichlidae recording the highest percentage abundance and also found to be most diverse. The anthropogenic activities around the river couple with over-exploitation of the fisheries resources were found accounted for the decline in the fishes composition and diversity of the river.
\end{abstract}

Volume 4 Issue 4 - 2020

\author{
Adebayo Ebenezer Temitope,' Ekeledo \\ Chukwunyere Bobo ${ }^{2}$ \\ Department of Biological Sciences, University of Medical \\ Sciences, Nigeria \\ 2Department of Fisheries Technology, Federal Polytechnic \\ Nekede, Nigeria
}

Correspondence: Adebayo Ebenezer Temitope, Department of Biological Sciences, University of Medical Sciences, Ondo City, Ondo State, Nigeria, Email adebayotemitopeet@gmail.com

Received: July 12, 2020 | Published: July 28, 2020

Keywords: anthropogenic, over-exploitation, diversity, composition

\section{Introduction}

The significance of fisheries resources in the socio-economic and food security development of any nations cannot be overemphasized, and the importance of fish as a source of protein is an indisputable fact. Apart from being a means of foreign exchange and cheap source of safe animal protein, fishery resource contains other essential nutrients required by the body for healthy living ${ }^{1,2}$ However, studies have shown that fish yield of most Nigerian inland water is on the decline, ${ }^{3}$ due to a wide range of causes ranging from environmental degradation of the water bodies to inadequate management of the fisheries resources. Ogueri et al., ${ }^{4}$ have establish that water quality of Otamiri River in the recent years is compromised due to the several anthropogenic activities around the river, hence the need to revalidate the fisheries composition and abundance of Otamiri River after several years of earlier studies of Orji Akobuche and Okereke, ${ }^{5}$ in order to have a update of the fish fauna as a precursor to advising on the most efficient use of the river for socio-economic development.

\section{Materials and methods}

\section{Study area description}

The study was carried out at the upper course of Otamiri River. Otamiri River is located within the tropical rainforest belt of Nigeria and lies between latitude $05^{\circ} 23^{\prime} \mathrm{N}$ to $05^{\circ} 30^{\prime} \mathrm{N}$, and longitude $6^{\circ} 58^{\prime}$ $\mathrm{E}$ to $7^{\circ} 04^{\prime} \mathrm{E}$ (Figure 1 ). The area is low lying being generally about $300 \mathrm{~m}$ above sea level. The river runs from Egbu, where it has its major recharge resource and cuts through Nekede, Ihiagwa, Eziobodo, Olokwumuisi, Mgbirichi, Umuagwo and finally to Ozuzuin Etche town of river state of Nigeria, where it finally joins to the Atlantic ocean. ${ }^{6}$ The region experiences a mean annual temperature of $27^{\circ} \mathrm{C}$ and an annual rainfall of $200-300 \mathrm{~mm}$, with most of the months (April to November) characterized with high rainfall. The river serves the aforementioned transverse communities as main sources of water for Industrial, Agricultural, and Domestic use.

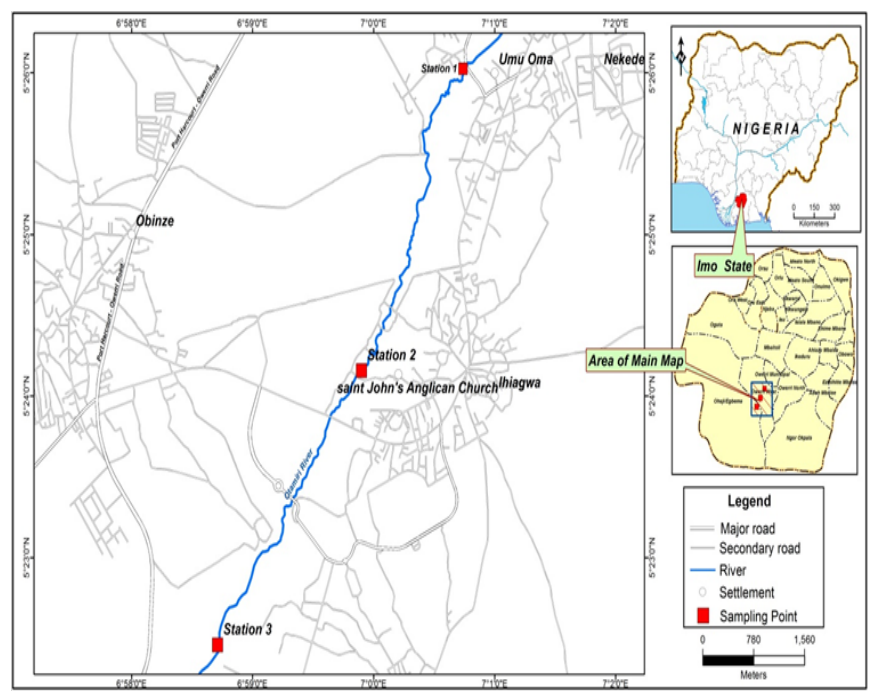

Figure I Map of Otamiri River showing the Sampling Stations (Sources: Cartographic Unit,University of Ibadan, 2019).

\section{Sampling design and analysis}

Three sampling stations were selected for the studies, and both water and fish samples were collected from the river bi-weekly for three months between the months of July to September, 2019. Sampling was done on the river between the hours of 8:00am $-12: 00 \mathrm{pm}$ on each of the sampling days. Surface water samples for chemical parameters were collected and analysed using a standard procedures. ${ }^{7}$ Likewise, data on fish species was collected bi-weekly using gill-net, cast-net, trammel-net, single hook and line, long-hook and line, mallea trap, wire basket trap throughout the sampling period. The number of fish caught in each sampling station were counted and recorded accordingly. The number of fish species caught by each of 
the fishing gear were also counted and recorded. The weights of each fish were obtained using digital weighing balance to the nearest $0.01 \mathrm{~g}$. The standard length, fork length and total length were also measured. Fish samples were counted sort out and identified using Nigeria freshwater identification scheme of Idodo-Umeh, ${ }^{8}$ and Olaosebika and Raji. ${ }^{9}$

\section{Statistical analysis}

Descriptive statistics was used to analyze data on the physicochemical parameter of the river. Duncan Multiple Range Test (DMRT) was employed to analyze the variation in the physico-chemical properties of the water samples across the three sampling stations. The analysis of the biological data was made with a combination of indices. Species diversity and evenness was determined with ShanonWiener's index (H), Margalef's index (D), and Equitability (J) using PAST Version 3.

\section{Result and discussion}

\section{The physico-chemical parameters}

The results of the physico-chemical parameters of the Otamiri River in Owerri West LGA of Imo State, southeastern Nigeria between the periods of July 2019 to September 2019 is shown that all the parameters measured fall within the NESREA ${ }^{10}$ recommended limit for aquatic management except the $\mathrm{pH}$, ammonia, total suspended solid, Nitrate and carbon (iv) oxides (Table 1), while Conductivity and carbon (iv) oxides were revealed to be significantly different across the sampling stations (Table 2). This finding corroborate the earlier report of Ogueri et al. ${ }^{4}$ and Adebayo et al. ${ }^{11}$ where the authors attributed the increased levels of those parameters to the erosional run-off of the adjourning lands due to the clearing of the riparian forest, and the sand dredging. Furthermore, the recorded fluctuation in the physico-chemical parameters (Figure $2-5$ ) could be attributed to the weather changes during the study period.

\section{Fish abundance and composition}

The check list of the encountered fish species during the study period is presented in Table 3 . Sixteen species belonging to nine families were recorded. These findings shows a decline in the fish composition of the river when compare with previous reports of Okoukwu $^{12}$ where he identified 20 fish species from 10 families from the river, and Okereke ${ }^{5}$ in her study on the river recorded 46 species belonging to 20 families. However, the study further affirms Cichlidae to be the most abundance of all the species during the study period. This could be attributed to the highly prolific nature of the family. Furthermore, the recorded highest abundance in the sampling station 1 could be attributed to the low water current in the stations couple with less dredging activities around the sampling station (Figure 6).

Table I Descriptive statistics of the Physico-chemical Parameters of Otamiri River between July and September, 2019

\begin{tabular}{llll}
\hline Parameters & Range & Mean \pm SE & NESREA (20I I) \\
\hline Temperature $\left({ }^{\circ} \mathrm{C}\right)$ & $24.60-28.00$ & $26.878 \pm 0.209$ & $\mathrm{a}$ \\
Transparency $(\mathrm{m})$ & $0.10-1.42$ & $0.901 \pm 0.085$ & $\mathrm{NS}$ \\
Current $(\mathrm{m} / \mathrm{s})$ & $0.10-1.12$ & $0.244 \pm 0.056$ & $\mathrm{NS}$ \\
$\mathrm{pH}$ & $0.50-6.00$ & $5.111 \pm 0.409$ & $6.5-8.5$ \\
Alkalinity $(\mathrm{mg} / \mathrm{L})$ & $16.00-32.00$ & $22.667 \pm 1.073$ & $\mathrm{NS}$ \\
Conductivity $(\mu \mathrm{S} / \mathrm{cm})$ & $8.00-45.00$ & $26.444 \pm 2.930$ & $\mathrm{NS}$ \\
Ammonia $(\mathrm{mg} / \mathrm{L})$ & $0.01-1.12$ & $0.623 \pm 0.085$ & $<0.1$ \\
Total Dissolved Solid $(\mathrm{mg} / \mathrm{L})$ & $2.00-23.00$ & $13.611 \pm 1.625$ & $\mathrm{NS}$ \\
Total Suspended Solid $(\mathrm{mg} / \mathrm{L})$ & $3.20-7.48$ & $5.597 \pm 0.320$ & 0.25 \\
Nitrate-Nitrogen $(\mathrm{mg} / \mathrm{L})$ & $0.05-0.10$ & $0.053 \pm 0.003$ & 9.1 \\
Dissolved Oxygen $(\mathrm{mg} / \mathrm{L})$ & $4.30-8.60$ & $6.653 \pm 0.323$ & Not $<6.0$ \\
Hardness $(\mathrm{mg} / \mathrm{L})$ & $16.00-52.00$ & $34.000 \pm 2.452$ & NS \\
Carbon IV Oxide $(\mathrm{mg} / \mathrm{L})$ & $26.00-72.00$ & $45.528 \pm 4.10 \mathrm{I}$ & $<20.0$ \\
Chloride $(\mathrm{mg} / \mathrm{L})$ & $38.00-68.00$ & $49.056 \pm 2.084$ & 300
\end{tabular}

SE, standard error of mean; NS, Not Specified; and a, a except in mixing zones, temperature increase by a 7-Day Average of the Daily Maximum temperatures (7-DADMax) shall not be more than $0.3^{\circ} \mathrm{C}$ above natural background conditions

Table 2 Spatial variation in Physico-chemical parameters of Otamirri River between July and September 2019, $(P<0.05)$ using Duncan Multiple Range Test (DMRT)

\begin{tabular}{llll}
\hline \multirow{2}{*}{ Parameters } & \multicolumn{3}{l}{ STATIONS } \\
\cline { 2 - 4 } & $\mathbf{I}$ & $\mathbf{2}$ & $\mathbf{3}$ \\
\hline Temperature $\left({ }^{\circ} \mathrm{C}\right)$ & $27.35^{\mathrm{a}}$ & $26.10^{\mathrm{a}}$ & $27.18^{\mathrm{a}}$ \\
Transparency $(\mathrm{m})$ & $0.89^{\mathrm{a}}$ & $0.97^{\mathrm{a}}$ & $0.85^{\mathrm{a}}$ \\
Current $(\mathrm{m} / \mathrm{s})$ & $0.24^{\mathrm{a}}$ & $0.14^{\mathrm{a}}$ & $0.46^{\mathrm{a}}$ \\
$\mathrm{pH}$ & $6.00^{\mathrm{a}}$ & $5.33^{\mathrm{a}}$ & $5.50^{\mathrm{a}}$ \\
\hline
\end{tabular}




\begin{tabular}{|c|c|c|c|}
\hline \multirow{2}{*}{ Parameters } & \multicolumn{3}{|c|}{ STATIONS } \\
\hline & I & 2 & 3 \\
\hline Alkalinity (mg/L) & $23.00^{\mathrm{a}}$ & $20.67^{a}$ & $24.33^{\mathrm{a}}$ \\
\hline Conductivity & $25.83^{\mathrm{ab}}$ & $11.83^{b}$ & $34.67^{a}$ \\
\hline Ammonia (mg/L) & $1.04^{\mathrm{a}}$ & $0.39^{a}$ & $0.74^{\mathrm{a}}$ \\
\hline Total Dissolved Solid (mg/L) & $14.17^{a}$ & $6.00^{a}$ & $17.83^{\mathrm{a}}$ \\
\hline Total Suspended Solid (mg/L) & $5.92^{\mathrm{a}}$ & $4.05^{a}$ & $6.25^{\mathrm{a}}$ \\
\hline Nitrate-Nitrogen (mg/L) & $0.06^{a}$ & $0.05^{a}$ & $0.05^{a}$ \\
\hline Dissolved Oxygen (mg/L) & $9.81^{a}$ & $5.18^{a}$ & $7.30^{\mathrm{a}}$ \\
\hline Hardness (mg/L) & $30.67^{\mathrm{a}}$ & $33.67^{\mathrm{a}}$ & $37.67^{\mathrm{a}}$ \\
\hline Carbon IV Oxide (mg/L) & $32.00^{\mathrm{b}}$ & $62.83^{\mathrm{a}}$ & $41.75^{b}$ \\
\hline Chloride (mg/L) & $46.67^{a}$ & $48.50^{a}$ & $52.00^{\mathrm{a}}$ \\
\hline
\end{tabular}

N.B,Values with the same superscript along same row are not significantly different at $P<0.05$

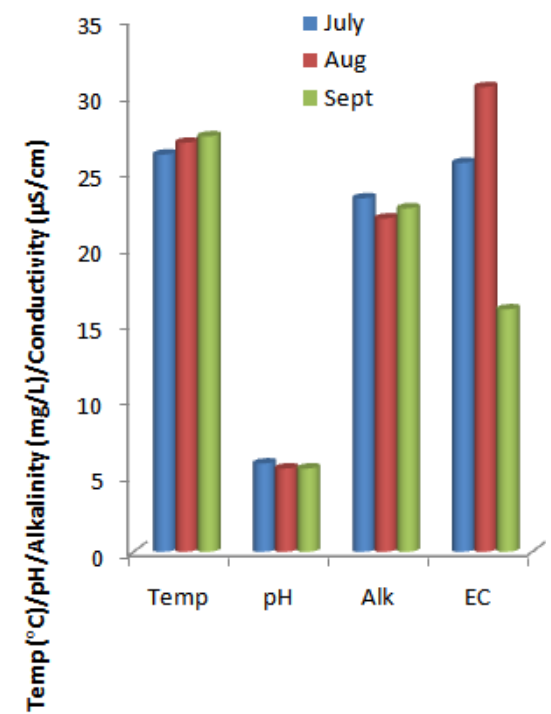

Figure $\mathbf{2}$ Temporal variations in mean water temperature, $\mathrm{pH}$, total alkalinity and electrical conductivity.

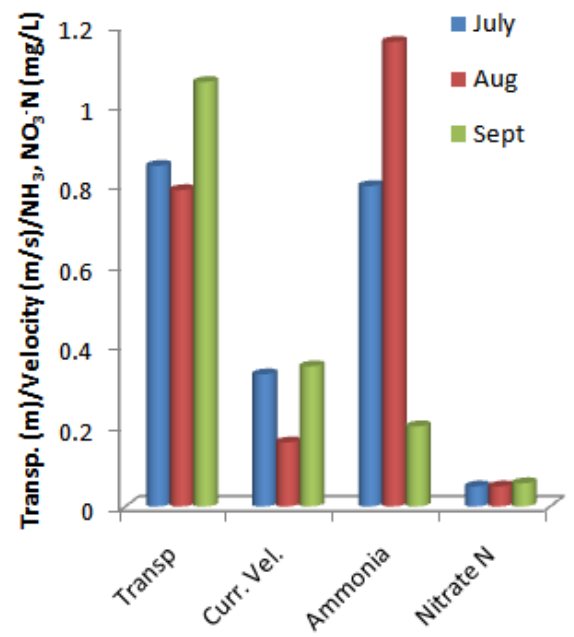

Figure 3 Temporal variations in mean transparency, current velocity,Ammonia and nitrate-nitrogen.

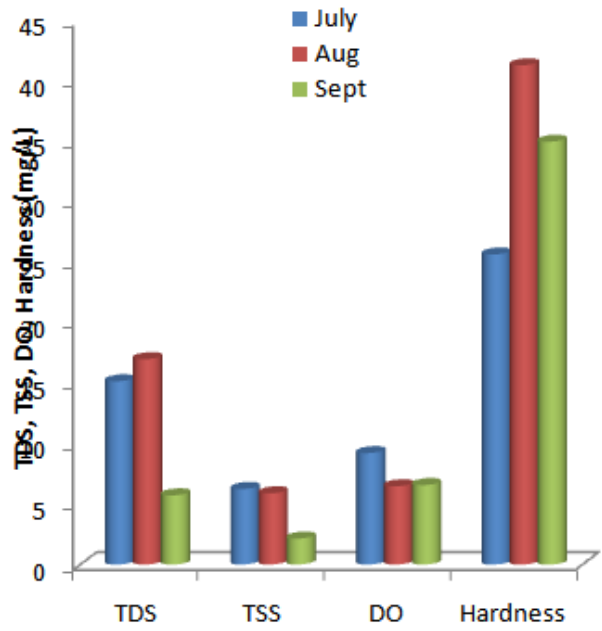

Figure 4 Temporal variations in mean total dissolved and suspended solids, dissolved oxygen and total hardness.

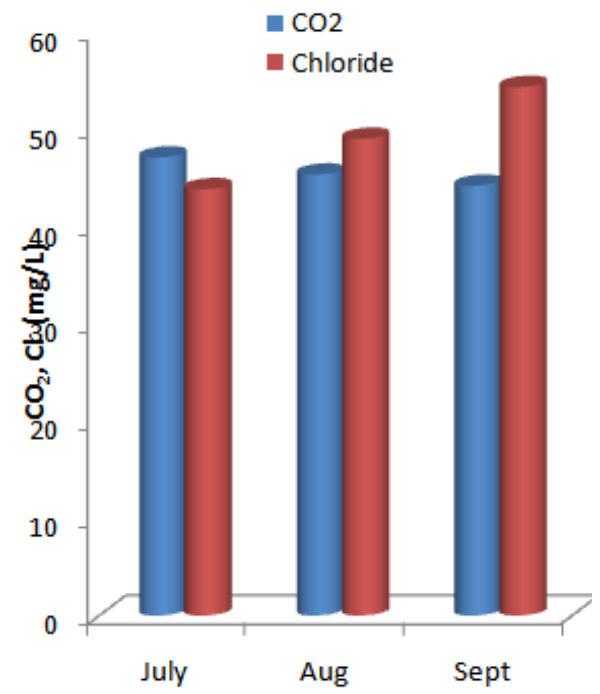

Figure 5 Temporal variations in mean dissolved carbon (IV) oxide and chloride ion. 
Table 3 The check list of the fish sample from Otamiri River between July to September 2019

\begin{tabular}{|c|c|c|c|}
\hline Family & Species & Total abundance & Percentage abundance \\
\hline \multirow{7}{*}{ Cichlidae } & Sarotherodon melanotheron & 526 & 59.7 \\
\hline & Hemichromis elongates & 14 & 1.6 \\
\hline & Coptodon zilli & 112 & 12.7 \\
\hline & Pelmatochromis guntheri & 3 & 0.3 \\
\hline & Tilapia dageti & 13 & 1.5 \\
\hline & Tilapia mariae & 14 & 1.6 \\
\hline & Tilapia guineensis & 3 & 0.3 \\
\hline Notopteridae & Papyrocranus afer & 79 & 9.0 \\
\hline Clarotidae & Chrysicthy nigrodigitatus & 46 & 5.2 \\
\hline Alestidae & Alestes macrolepidotus & 39 & 4.4 \\
\hline Hepsetidae & Hepsetus akawo & 7 & 0.8 \\
\hline \multirow{2}{*}{ Mormyridae } & Mormyrops deliciosus & 19 & 2.2 \\
\hline & Petrocephalus bane & I & 0.1 \\
\hline Gymnarchidae & Gymnarchus niloticus & $\mathrm{I}$ & 0.1 \\
\hline Channidae & Parachana obscura & I & 0.1 \\
\hline Cyrinidae & Barbus occidentalis & 2 & 0.2 \\
\hline Grand Total & & 880 & 100 \\
\hline
\end{tabular}
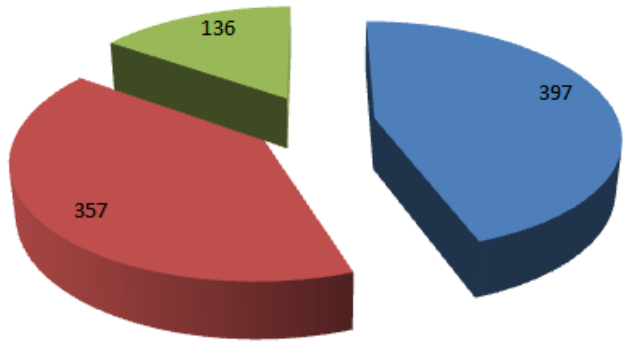

atation 1

- Station 2

Station 3

Figure 6 Total fish abundance of Otamiri River between July-Sept. 2019.

\section{Fish diversity}

The diversity index and spatial diversity index of total fish species recorded in the Otamiri River during the study period is shown in Table $4 \& 5$ respectively. Cichlidae was revealed to be most diverse throughout the study period. This could be due to the suitability of the environment. Also, the highest diversity was recorded in station 3 during the study period. This finding agreed with the report of Offem et al., ${ }^{13}$ on wetlands of Cross River where he observed that habitat size and heterogeneity increased along up river- down river axis but flow variability decreased at down-river localities. ${ }^{14}$

Table 4 Diversity indices of total fish species caught in Otamiri River during the study period

\begin{tabular}{lllll}
\hline Taxa & H & J & E & Q \\
\hline Cichlidae & 3.81 & 12.38 & 0.55 & 0.87 \\
Notopteridae & 2.98 & 5.26 & 0.82 & 0.94 \\
Clarotidae & 2.83 & 4.70 & 0.89 & 0.96 \\
Alestidae & 2.70 & 4.91 & 0.79 & 0.92 \\
Hepsetidae & 1.95 & 3.08 & 1.00 & 1.00 \\
Mormyridae & 2.18 & 3.00 & 0.89 & 0.95 \\
Gymnarchidae & 0.00 & 0.00 & 1.00 & 0.00 \\
Channidae & 0.00 & 0.00 & 1.00 & 0.00 \\
Cyrinidae & 0.69 & 1.44 & 1.00 & 1.00
\end{tabular}

$H$, shanon weiner's; J, margarlef index; E, evenness; $Q$, equitability 
Table 5 Spatial diversity indices of total fish species caught in Otamiri River during the study period

\begin{tabular}{|c|c|c|c|c|c|c|c|c|c|c|c|c|}
\hline \multirow[b]{2}{*}{ Taxa } & \multicolumn{4}{|c|}{ Station I } & \multicolumn{4}{|c|}{ Station 2} & \multicolumn{4}{|c|}{ Station 3} \\
\hline & $\mathbf{H}$ & $\mathbf{J}$ & $\mathbf{E}$ & $\mathbf{Q}$ & $\mathbf{H}$ & J & $\mathbf{E}$ & $\mathbf{Q}$ & $\mathbf{H}$ & J & $\mathbf{E}$ & $\mathbf{Q}$ \\
\hline Cichlidae & 2.49 & 3.07 & 0.63 & 0.85 & 2.81 & 5.09 & 0.60 & 0.84 & 3.13 & 5.18 & 0.95 & 0.98 \\
\hline Notopteridae & 1.85 & 2.23 & 0.79 & 0.89 & 2.07 & 0.94 & 0.88 & 0.94 & 1.82 & 2.16 & 0.88 & 0.94 \\
\hline Clarotidae & 1.66 & 2.01 & 0.88 & 0.93 & 2.02 & 2.20 & 0.94 & 0.97 & 1.51 & $\mathrm{I} .74$ & 0.90 & 0.94 \\
\hline Alestidae & 1.27 & $\mathrm{I} .37$ & 0.89 & 0.92 & 1.50 & 1.73 & 0.75 & 0.84 & 2.14 & 3.22 & 0.94 & 0.97 \\
\hline Hepsetidae & 0.69 & $\mathrm{I} .44$ & 1.00 & 1.00 & 0.69 & $\mathrm{I} .44$ & 1.00 & 1.00 & 1.09 & $\mathrm{I} .82$ & 1.00 & 1.00 \\
\hline Mormyridae & 0.69 & $\mathrm{I} .44$ & 1.00 & 1.00 & 1.21 & $\mathrm{I} .44$ & 0.84 & 0.88 & 1.37 & 1.30 & 0.98 & 0.99 \\
\hline Gymnarchidae & - & - & - & - & 0.00 & 0.00 & 1.00 & 0.00 & - & - & - & - \\
\hline Channidae & - & - & - & - & 0.00 & 0.00 & 1.00 & 0.00 & - & - & - & - \\
\hline Cyrinidae & - & - & - & - & 0.69 & 1.00 & 1.00 & 1.00 & - & - & - & - \\
\hline
\end{tabular}

$\mathrm{H}=$ Shanon Weiner's

$\mathrm{J}=$ Margarlef index

$\mathrm{E}=$ Evenness

$\mathrm{Q}=$ Equitability

\section{Conclusion}

This study has vividly established a threat in the composition, abundance and the diversity structure in the fisheries of Otamiri River which has resulted in the elimination of some species probably to their high flesh values from the river. The possible threat could be attributed to poor management practices around the river, and the overexploitation of the resources from the surrounding populace. Thus the necessary measures to ensure the rejuvenating of these resources should be quickly implemented. Likewise, the anthropogenic activities around the river should be checked.

\section{Acknowledgments}

None.

\section{Conflicts of interest}

Authors declare no conflict of interest exists.

\section{Funding}

None.

\section{References}

1. Sikoki FD, Otobotekere AJT. Fisheries. In: Alagoa EJ, Editors. The Land and People of Bayelsa State. Central Niger Delta. Onyoma Research Publications, Port Harcourt. 1999;307-319.

2. Aarts GWB, Nienhuis PH. Fish zonations and guilds as the basis for assessment of ecological integrity of large Rivers. Hydrobiologia. 2003;500:157-178.

3. Jamu DM, Ayinla AO. Potential for the development of aquaculture in Africa. Naga. 2003;26:9-13.

4. Ogueri C, Adebayo ET, Ekeledo CB. Spatial evaluation of benthic macroinvertebrates along the upper course of otamiri river, imo - state, Nigeria. Journal of Global Biosciences. 2018;7(6):5439-5451.
5. Okereke FO. Studies on the fish fauna of Otamiri River. Imo State; Nigeria M. Sc Thesis, University of Potharcourt, Choba. 1990.

6. Anyanwu DC. A comparative evaluation of early rain phytoplankton productivity of Nworie River and Otamiri River, Owerri Imo State. NIEROA, Department of Agricultural Science, Alvan Ikoku College of Education Retrieved. 2009;10-14.

7. American Public Health Association-APHA. Standard Methods for the Examination of Water and Wastewater. 20th ed. APHA/AWWA/WEF: Washington DC. USA. 1998; p. 1213.

8. Idodo-Umeh G. Freshwater Fishes of Nigeria. Idodo Umeh Publishers Nigeria. 2003;229.

9. Olaosebika BD, Raji A. Field guide to Nigeria Freshwater fishes. Publ. by Federal College of Freshwater Fisheries Technology, Revised Ed. Uniilorin printing press. 2013;144.

10. National Environmental Standards and Regulations Enforcement Agency (NESREA). National Environmental (Surface and Groundwater Quality Control) Regulations. Federal Republic of Nigeria Official Gazette No. 49. $2011 ; 98$.

11. Adebayo ET, Ebeniro LA, Oyediran AG, et al. An Assessment of Benthic Macro-invertebrate Fauna in Middle Course of Otamiri River, Imo State, South-Eastern Nigeria, Nigeria. International Journal of Innovative Studies in Aquatic Biology and Fisheries (IJISABF). 2016;2(1):29-35.

12. Okoukwu UC. Fish catch assessment of upper course of Otamiri. B. Sc thesis, Department of Fisheries and Aquaculture Technology, Federal University of Technology, Owerri. 2012;53.

13. Offem BO, Samson YA, Omoniyi IT. Fish composition and abundance in the wetlands of Cross River, Nigeria. Aquatic Ecology. 2009;1:2-10.

14. Olaosebikan BD, Raji A. Nigeria Freshwater Fishes. Remi Thomas Press, New Bussa, Nigeria. 2013;144. 